\title{
Status of Coconut Farming and the Associated Challenges in Kenya
}

\author{
Pole F.N. ${ }^{*}$, E. Masha ${ }^{2}$, F.K. Muniu ${ }^{1}$, B. Nguma ${ }^{2}$, and N. Mohammed ${ }^{3}$
}

\begin{abstract}
Coconuts (Cocos nucifera) have been grown in Coastal Kenya for many centuries and are an integral part of the farming systems in the region. Over $80 \%$ of the coastal farm households derive their livelihoods either directly or indirectly from the coconut tree that is considered as both cash and a food crop. The coconut tree on the other hand has a tremendous potential of helping Kenya's poor in the coastal region and the rest of the country due to its multi-purpose uses that can be strategically harnessed to generate employment and income, reduce edible oil imports and generate foreign exchange for the country. The tree population stands at 7.5 million palms. Nut production is however very low (a minimum of 30 nuts per tree per year) owing to a number of challenges that include high incidences of pests and diseases, poor agronomic practices, low quality planting materials and a narrow genetic base. In order to address the major challenge of coconut pests, a baseline survey was undertaken in the major coconut producing counties of coastal lowland Kenya, targeting the smallholder coconut farmers. A total 170 farmers were interviewed using a structured questionnaire. A literature review was also conducted to contextualize and benchmark findings of the survey. Results showed that the rhinoceros beetle was the major pest on coconut trees, causing damage of up to $80 \%$ of the palms. The Coreid bug (Pseudotheraptus wayi) and the Eriophyid mites (Aceria guerreronis) were the major nut destructive pests with a resultant nut loss of $30 \%$ and $40 \%$ respectively. The study stresses the need to address the challenges posed by pests and diseases on coconut by adopting the Integrated Pest and Disease Management (IPDM) practices.
\end{abstract}

Keywords: Coconut, pests, rhinoceros beetle, Coreid bug, Eriophyid mites.

\footnotetext{
${ }^{1}$ Kenya Agricultural Research Institute, P.O. Box 4, Matuga 80406, Kenya.

Email: karimatuga@yahoo.co.uk/ finyange@gmail.com*

${ }^{2}$ Kenya Coconut Development Authority, P.O. Box 84351-80100, Mombasa, Kenya.

Email: info@kcda.go.ke

${ }^{3}$ Pwani University (Kilifi-Kenya), P.O. Box 195-80108, Kilifi, Kenya.

Email: najy21@hotmail.com
} 


\section{Introduction}

Coconuts (Cocos nucifera) have been grown in Coastal Kenya for many centuries and are an integral part of the farming systems in the region. It was introduced to Kenya in the $16^{\text {th }}$ century by the Portuguese. Coconut cultivation spread rapidly and became an industrial crop of economic importance during the $20^{\text {th }}$ century. Production and marketing was handled by the Arab traders and white settlers in big plantations until the $19^{\text {th }}$ century when small-scale farmers started growing the crop. Currently, coconut production is being undertaken by the smallholder farmers. Over $80 \%$ of the coastal farm households derive their livelihoods either directly or indirectly from the coconut (Gachanja et.al, 2007). In coastal Kenya, coconut is considered as both a food and a cash crop. As a food crop, the coconut tree provides food security owing to its continuous production of the nuts throughout the year that can be consumed either at their tender stage (madafu) or when they are mature (Sharma, 2006). The crop on the other hand has a tremendous potential of helping Kenya's poor in coastal region and the rest of the country due to its multi-purpose uses that can be strategically harnessed to generate employment and income, reduce edible oil imports and generate foreign exchange for the country. The coconut tree generates over 100 different products that can enter both the domestic and international markets. On health benefits, East African's drunk a cup of coconut oil whenever they were sick. Moreover coconut oil is rich in lauric acid which is reported to slow down multiplication of the HIV virus and can also reduce the mother to child transmission on HIV (Anon, 1999 and 2001; Fife, 2005). It is also reported that populations that use coconut oil have lowest rates of heart diseases and cancer.

A coconut baseline survey conducted by Gachanja in 2007 indicated that there are 7.4 million coconut trees in Coastal Kenya, contributing a total of KES 3.2 billion to the economy. Majority of those trees are found in Kwale and Kilifi Counties, with the tree population growing at the rate of $2.2 \%$ per year. The coconut trees produce a total of 162 million nuts per year that earns the farmers a farm gate income of about KES 0.8 billion, which is $24 \%$ of the total income from the coconut sub-sector; with palm wine generating $60 \%$ and roofing materials made from palm leaves contributing $12 \%$ of the total revenue generated by the coconut sub-sector.

However, the coconut sub-sector is challenged with a serious problem of low productivity. This could be attributed to poor management of the coconut plantations with many of the trees being left unattended in the bushes. Most groves are full of non-productive trees that are more often felled for timber and poles. This has led to the production of tiny nuts of low quality that fetch low prices in the market. Inadequate planting materials are another major production constraint. In the early 1970's the government established some coconut nurseries Msambweni and Kilifi districts with an aim of helping the farmers with high quality planting materials in order for them to either replace the old trees or establish new plantations. However, the programme was discontinued in the early 1980's when the government withdrew its support. This resulted in farmers planting their own seed without considering the age and yield of the tree from where the seed has been selected. On the side of coconut research, there was for a long time lack of clear policy direction for the Industry. National research priorities had given coconut a low rating thus limiting research in coconut due to inadequate funding. There are also inadequate and appropriate technologies in the field of agronomy, pest and disease control as well as post-harvest handling and processing that have been developed for adoption by smallscale farmers. Furthermore the Genetic base for the Kenyan palm is low compared to other countries in Africa as it is limited to the East African Tall and only one dwarf variety (Gachanja et.al 2007), with no studies having being conducted to determine the diversity of the East African Tall. The establishment of the Kenya Coconut Development Authority (KCDA) has been seen as a move in the right direction in trying to address these challenges. Major limiting factors in coconut production are incidences of the Rhinoceros beetle and the 
Coconut Bole Rot. This has led to the death of many coconut trees in the region thereby reducing the tree population to a great extent. The pest menace is so severe that most farmers (95\%) reported that their palms in the farms are affected in one way or the other. The Rhinoceros beetle in particular has contributed more to the coconut tree damage due to its ability to multiply at a higher rate as a result of the breeding sites available in the coconut fields. Their ability to fly has also made it easy to spread fast and cause destruction from one region to the next. In addition, it poses a great challenge to control them by use of chemical means since the trees are very tall. In an attempt to address the challenges posed by coconut pests and diseases, a study was taken to assess the incidence and damage potential of key pests and diseases of coconut palm in Kenya and to evolve pest and disease management strategies.

\section{Materials and methods}

\section{Study area}

The study was conducted in Kwale, Kilifi, Tana River and Lamu Counties of coastal Kenya. These are the major coconut growing areas in coastal Kenya where the tree population is high.

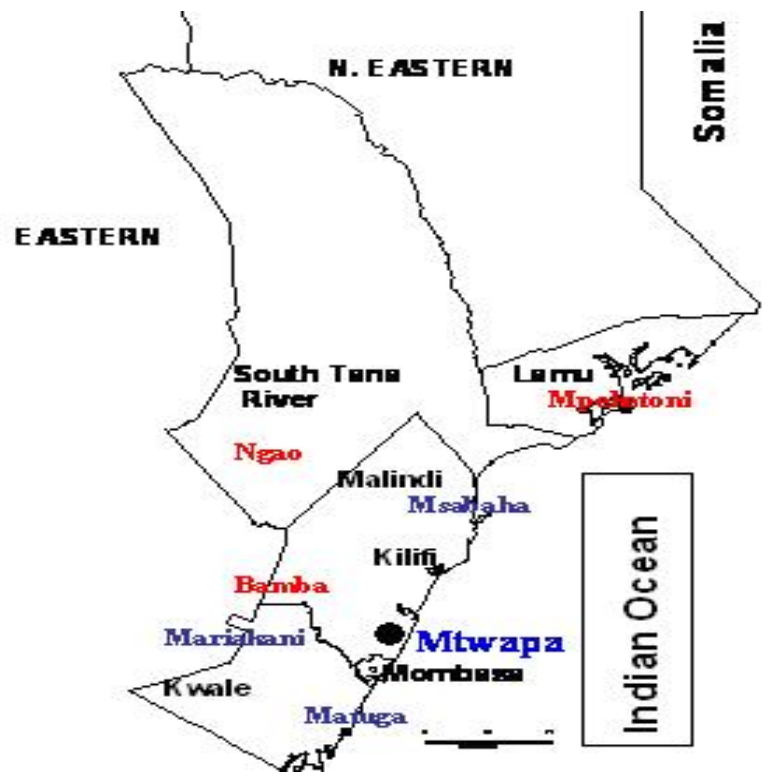

Figure 1. Map of Coastal Kenya

Coastal Kenya (formally Coast Province) is a region that borders the Indian Ocean. It was one of the Kenya's eight provinces and comprises of Kwale, Mombasa, Kilifi, Tana River, Lamu and Taita-Taveta Counties. It covers an area of $79,686.1 \mathrm{Km}^{2}$ with a population of $3,325,307$ inhabitants (KNBS 2009). The population distribution county wise is as follows:

Table 1. Population distribution in Coastal Kenya

\begin{tabular}{|c|l|c|c|c|l|}
\hline Code & \multicolumn{1}{|c|}{ County } & Former Province & Area $\left.\mathbf{( k m}^{\mathbf{2}}\right)$ & Population Census 2009 & \multicolumn{1}{|c|}{ Capital } \\
\hline 2 & Kwale & Coast & $8,270.3$ & 649,931 & Kwale \\
\hline 1 & Mombasa & Coast & 212.5 & 939,370 & Mombasa \\
\hline 3 & Kilifi & Coast & $12,245.9$ & $1,109,735$ & Kilifi \\
\hline 4 & Tana-river & Coast & $35,375.8$ & 240,075 & Hola \\
\hline 5 & Lamu & Coast & $6,497.7$ & 101,539 & Lamu \\
\hline 6 & Taita-Taveta & Coast & $17,083.9$ & 284,657 & Voi \\
\hline Totals & $\mathbf{7}$ Counties & Coast & $\mathbf{7 9 , 6 8 6 . 1}$ & $\mathbf{3 , 3 2 5 , 3 0 7}$ & Mombasa \\
\hline
\end{tabular}

Source: Wikipedia Free Encyclopaedia (en.wikipedia.org/wiki/Coast Province) 


\section{Agricultural land}

Coast Province covers a total area of $82,816 \mathrm{Km}^{2}$ with $32,529 \mathrm{Km}^{2}$ (39\%) suitable for crop production and the remaining $61 \%$ is Arid and semi-Arid land (ASAL) supporting livestock production and game parks. The coastal area supports 252.090 farm families with majority (32.2\%) found in Kwale, $21.6 \%$ in Kilifi 17.3\% in Taita Taveta and $13.7 \%$ in Malindi.

\section{Sampling}

The farm household was identified as the unit of analysis. To comprehensively cover the objectives of the survey, the following major activities were undertaken:

- $\quad$ Literature Review of relevant documents from various sources relating to the topic under study.

- $\quad$ Field Interviews with coconut farmers in the counties. This was carried out through structured questionnaires to help in gathering some specific information on coconut farming and its challenges in coastal Kenya.

\section{Baseline survey}

In order to determine the current status of coconut pests in the targeted Counties a baseline survey was conducted to establish bench marks for technological interventions. A structured questionnaire was developed and administered to 170 coconut farming households in the major coconut growing areas of Kwale, Kilifi, TanaRiver and Lamu Counties respectively. The criterion for selecting the households was based on the number of farmers in a Ward within a County. A total of 50 households each were selected in Kwale, Kilifi and Lamu Counties while in Tana River County, 20 questionnaires were administered in Kipini Ward which is the only major coconut producing area in the County. The purposive and systematic sampling procedure was applied. Both qualitative and quantitative data was collected in a bid to understand the socio personal and economic characteristics of the coconut farmers, level of production and production costs as well as the extent in which the coconut pests have caused destruction to the trees. The information obtained was analyzed to ascertain the effectiveness and efficiency of the value chains and at the same time; to form the basis of completing the various gaps in the coconut chain.

\section{Data analysis}

The results were keyed in using the MSExcel software. Analysis was carried out by the use of descriptive and inferential statistics in the statistical package for the social sciences (SPSS) which enabled the generation of critical parameters of importance to the study that are presented in the form of tables, graphs and charts in later chapters of this report.

\section{Results and discussions}

\section{Gender}

A total of 170 farmers were interviewed in the coconut farming households. Out of these, $74.3 \%$ were male and $25.7 \%$ were female. The results show that more of the male farmers are actively involved in coconut farming than their female counterparts. This is so because coconut is regarded as a crop for the male type of gender. In the cases where there were female household heads, the male counterparts were either away for other duties or they had passed on and the woman was in-charge of the household.

\section{Age bracket of the respondents}

The respondents were of different age groups and the youngest was 30 years while the oldest was 95 years. The respondents were grouped together in classes of ten years and the results show that the respondents in the age bracket of 40 to 49 were more than the rest at $31.7 \%$ followed by 30 to 39 with $25.1 \%$ and 50 to 59 years at $21.8 \%$ respectively. Those that were over 60 years were $21.4 \%$. This is an indication that there are some youthful coconut farmers in the coconut subsector who are taking an active role in the farming of the crop.

\section{Family Size}

The size of the family was an average of 6 persons for $19.9 \%$ of the households while those families with a range of 5-8 persons was $57.2 \%$ 


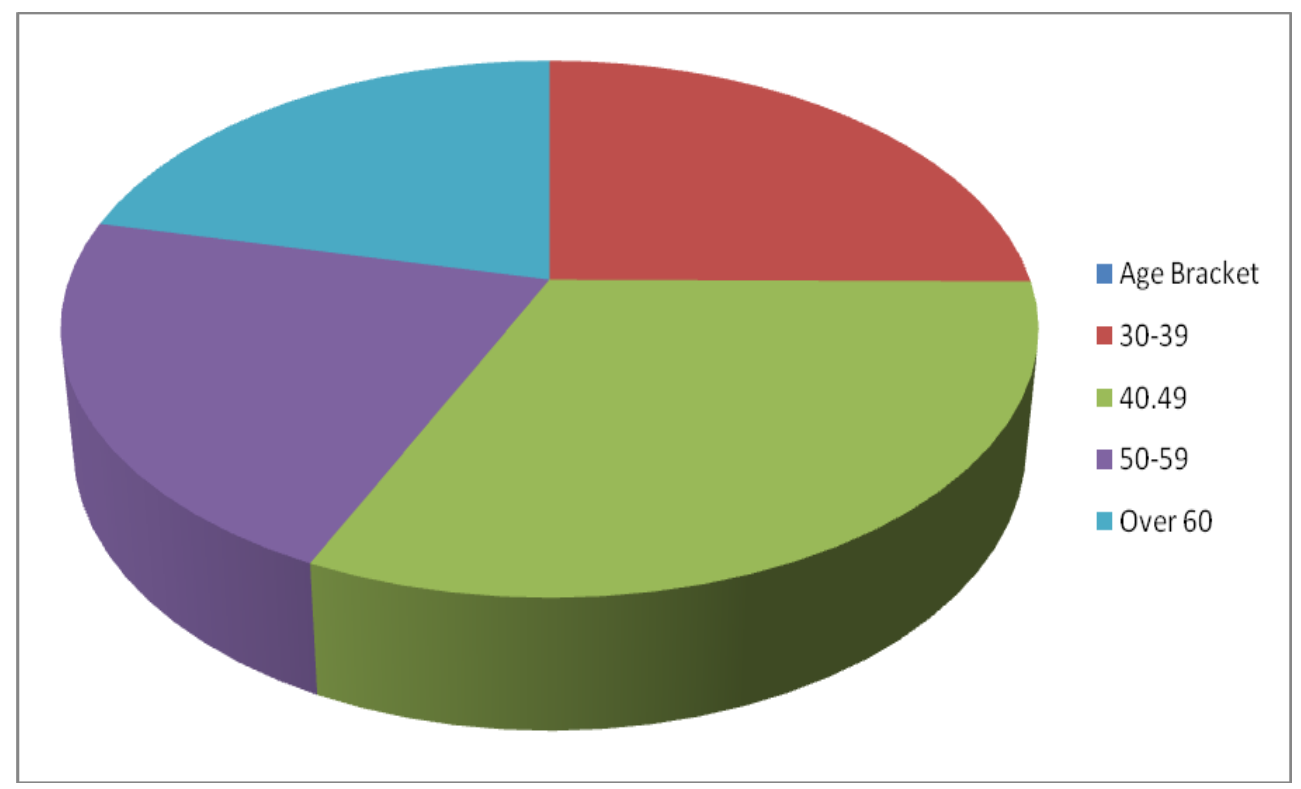

Figure 2. Proportions of coconut farmers by age

of the sampled population. As regards to the level of education $49.4 \%$ of the household heads were educated up to primary level while $30.6 \%$ had reached secondary school and other institutions of higher learning. The respondents on the other hand belonged to households of varying categories. Of the total number interviewed, $76.7 \%$ of the respondents were in a household type that was male headed, while the households headed by wife or wives were $15.2 \%$ followed by $8.1 \%$ comprising of either female headed, divorced, single or widowed.

\section{Land sizes}

The holding size of coconut farms ranged from 0.25 acres to more than 30 acres. Majority of the farmers $(65 \%)$ however, had planted the coconut trees in farm sizes ranging from 0.25 acres to 5 acres, while others $(21.5 \%)$ had farm sizes of between 5 acres and 15 acres and the rest $(13.5 \%)$ had more than 15 acres.

\section{Land and coconut tree ownership}

Ownership of the land meant that the farmers were able to make long term decisions to the development of the land and 37.2\% owned the land and had a title deed to it while $62.8 \%$ who owned the land didn't have a title for it. Again, the ownership of coconut trees was diverse. Among the respondents interviewed, $15 \%$ owned the trees, $62 \%$ reported that the trees belong to the extended family, while $16 \%$ reported that the trees belonged to their parents. The trees that belong to the entire extended family in most cases exhibit some great challenges in regard to their management. In most cases they are left unattended in the bushes thereby leading to low quality nuts. There is also the lack of control in the harvesting of the nuts.

\section{Coconut farming}

The coconut palm is one of the enterprises that majority $(85 \%)$ of farmers in coastal Kenya heavily depend on for food as well income generation. Profitability however depends on the maximum utilization of the factors of production while reducing costs. The size of land a crop is produced combined with inputs (quality planting materials, fertilizers, and pest and disease management) and good agricultural practices gives the farmer better returns to investment. The survey revealed that coconut is produced in farm sizes ranging from 0.25 acres to 30 acres. Majority of the farmers $(65 \%)$ however, have planted the coconut trees in farm sizes ranging from 0.24 acres to 5 acres, while others $(21.5 \%)$ have farm sizes of between 5 acres and 15 acres and the rest $(13.5 \%)$ have more than 15 acres. 
Most of the coconut trees (45\%) are in the ages ranging from 30-60 years and this category of trees are the highest producers of both nuts and palm wine. $35 \%$ of the trees are aged between 5 and 29 years while the rest $(30 \%)$ are over 60 years of age, with minimum production of both nuts and wine. As regards to their involvement in coconut farming, many of the farmers (97\%) were involved in coconut production. However, most of these farmers $(65 \%)$ were not involved in planting the trees but inherited them from their parents and have continued managing them. Some of the farmers $(27 \%)$ have been involved in establishing new trees within the same plantations in addition to maintaining the old groves while $15 \%$ of the farmers started planting the trees from seedlings in newly opened lands. The number of years in which the farmers have been involved in coconut farming ranged from 5 to 55 years.

\section{Coconut Varieties Grown by the Farmers}

Majority of the farmers (98.33\%) grew the East African Tall (EAT) variety with the rest growing a mixture of the tall and the dwarf varieties respectively. The dwarf type of coconut tree is however very few in the farmers' fields. The respondents planted coconut trees with planting materials sourced from their own seed $(54.96 \%)$ and from family members $24.18 \%$. The rest of the respondents $(20.84 \%)$ had sourced the seedlings from government institutions like KARI and KCDA as well as trained nursery operators from their respective areas.

\section{Current yields of coconuts in the farms}

The respondents were all aware of the maturity period for a young coconut tree. The yield realization was from5-7 years for a newly established coconut tree of the East African Tall (EAT).The dwarf variety started to bear from 3-5 years after planting. Harvesting of mature nuts was done when the nuts dry up on the tree and fall down on the ground where they are collected and stored. These kinds of nuts offer the best quality in terms of oil production. They are also the best for seedlings production. However, very few $(25.4 \%)$ of the respondents harvest their nuts when they have dried up and falling down the ground while most of them $(68.6 \%)$ harvested them by climbing the trees and felling the nuts when they are mature but with their husks still green in colour. The farmers indicated that there are two main harvesting seasons for coconuts during the year. The first season starts in December and ends in March. The second season on the other hand begins in August and ends in October. The number of harvested nuts per tree per year depends on the amount of rainfall experienced in a region during the year, management levels of the trees, pest and disease incidences. These factors also contribute to the quality of the nuts in terms of the size and the amount of meat in the nut. Most of the respondents $(45.6 \%)$ interviewed indicated that their coconut trees yielded 30 nuts per tree year. Some of them $(31.2 \%)$ gave a figure of 50 nuts per tree per year while the rest $(23.2 \%)$ indicated that their trees yielded 70 nuts per tree per year. Prices for the nuts ranged from KES5.00 to KES 10.00 per nut. Majority of the farmers $(87 \%)$ sold the nuts at KES 5.00 especially during the peak harvesting periods. Farmers sold the nuts locally at the farm gate to traders who in turn sold the nuts to consumers in the urban towns and to buyers from the neighbouring country of Tanzania. The respondents indicated that production of coconuts was faced by a number of challenges. The challenges include lack of high yielding varieties (15\%), inadequate quality planting materials $(18 \%)$, poor husbandry practices (16\%), drought $(13 \%)$, inadequate processing skills $(9.0 \%)$, incidences of pests and diseases $(22 \%)$ Other farmers $(5 \%)$ indicated that there was a limited crop genetic base. The challenges highlighted by the farmers agree with the findings by Gachanja et.al 2007 while undertaking a coconut tree census in the region. There is a need to come up with appropriate intervention technologies aimed at addressing these challenges.

\section{Pests and diseases}

Pests and diseases pose a threat to coconut production in coastal Kenya. This could be attributed to the high temperatures and humidity that provide a conducive environment for the breeding and rapid multiplication of pathogens and insect pests. Over $95 \%$ of the respondents 


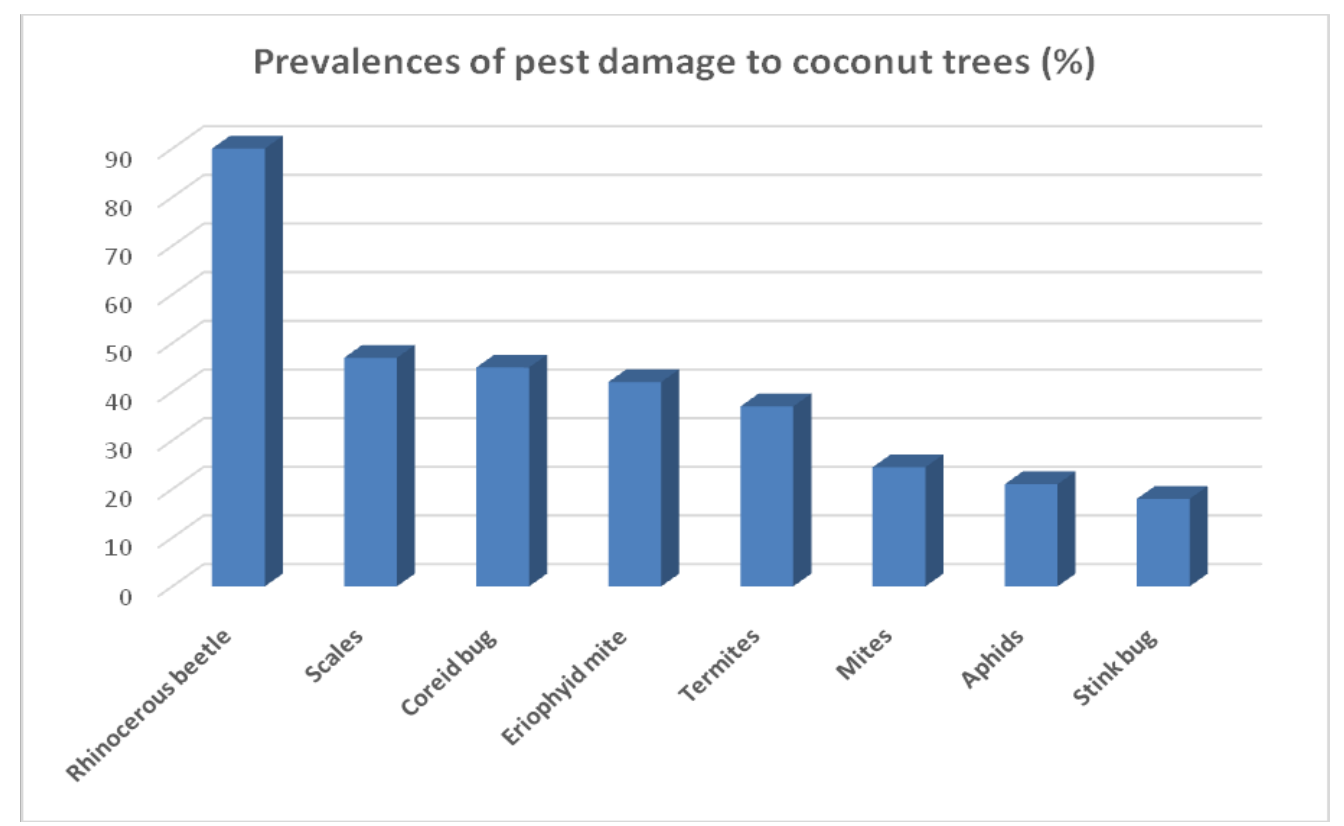

Figure 3. Severity of damage to coconut trees by pests

indicated that they had a problem with pests on their trees and they could identify like termites, mites, stink bug, aphids, scales, rhinoceros beetle, Coreid bug and the Eriophyid mite. The Coreid bug and the Eriophyid mite however were identified by the farmers through descriptions of the symptoms and the kind of damage that the pests cause to the nuts. A large proportion $(90 \%)$ of the farmers interviewed had a problem with the rhinoceros beetle damage to the trees in their farms, $35 \%$ termites, $47 \%$ scales, $24.5 \%$ mites, $18 \%$ stink bug, $21 \%$ aphids, $45 \%$ Coreid bug and $42 \%$ Eriophyid mite. The damage by the rhinoceros beetle to the palms was so severe that 8 out of 10 palms in the farms $(80 \%)$ were damaged by the beetle.

Observations made to the farms where the respondents were interviewed revealed that $96 \%$ of the farms had coconut waste and other trashes that provided a suitable environment for the breeding of the rhinoceros beetle. Most (58.4\%) of the farms visited had heaps of coconut husks, dead coconut tree logs, coconut leaves and fronds, cattle/poultry manure and other trash from the coconut trees. Other $(26.8 \%)$ farms contained heaps of the coconut husks, dead coconut tree trunks, coconut leaves and fronds and manure while the rest (14.4\%) contained the coconut husks, dead coconut trees and manure. Among the control measures that the farmers use include the use of ash (12\%), manual scouting and killing them using a metal rod (8\%) and use of sand (15\%). Majority (65\%) of the farmers did not have an idea on how to control the pest.

The rhinoceros beetle (Oryctes monoceros Olivier) poses a threat to the coconut trees. The newly planted coconut plants in particular are succumbing to the pest damage. There have been some attempts to control the pest in the past by use of several methods by researchers at Mtwapa in the 70's. One of the methods was the organization of a competition between schools for hunting and capturing the beetles and or their larvae. A financial award was then given to the school that had the highest number of catches. There was also the compulsory uprooting and burning of dead coconut palms and cleaning of coconut related trash in the coconut farms in a bid to reduce the breeding sites for the beetle. Some pheromone traps were also used to attract and catch the beetles that were later on killed. This practice was later discontinued due to inadequate funding. The other pests that were found to be damaging the coconut palms were termites and mites. The termites in particular damage the palms at their young development 
stages. Farmers who establish coconut farms by planting seed nuts directly in the seedbeds have experienced a lot of destruction to the nuts leading to poor germination as a result of the termite damage. During the survey, almost all the farmers indicated that the termites are a major problem to the young plants during the dry seasons when the termites look for green matter to feed on and some moist places especially underground where they make tunnels and hide. They however indicated that termites are easy to control by use of pesticides such as ZetaCypermethrin + Abamectin (Gladiator) which is usually mixed with water and sprayed around the planting hole or the base of the coconut tree, use of ash and some live plants that push away the pests.

Plate 1. A young coconut palm heavily damaged by Rhinoceros beetle

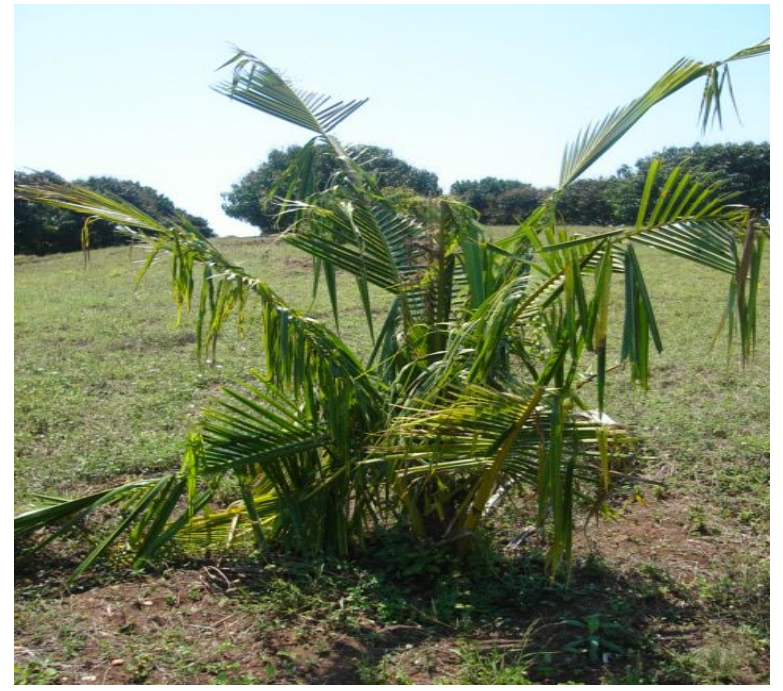

\section{Pests of the nuts}

Some pests were found to damage the young nuts. These were the Coreid bug (Pseudotheraptus wayi Brown) and the Eriophyid mite.

\section{Coreid bug (Pseudotheraptus wayi Brown)}

This is an insect that sucks sap from young nuts and even cashew nuts. They can cause damage of up to $80-90 \%$ of the total crop. The nymphs and adults suck young nuts that are 1-5 months old leading to:
- $\quad$ Premature nut fall

- $\quad$ Badly scarred and gumming nuts

- $\quad$ Small nuts with less copra

- $\quad$ Poor husk quality

It is one of the most serious coconut insect pests that cause severe destruction to coconuts. The insect is said to be very rampant in the East African region. During the survey, it was observed that at least $30 \%$ of the palms had their nuts damaged by the Coreid bug. Since the pest flies from one place to the next with some alterative host plants, there is need to come up with some biological control technologies in order to reduce the rate of destruction. The figures below indicate the destruction of the nuts by the pest.

Plate 2. Adult Bug entering the nut through bract

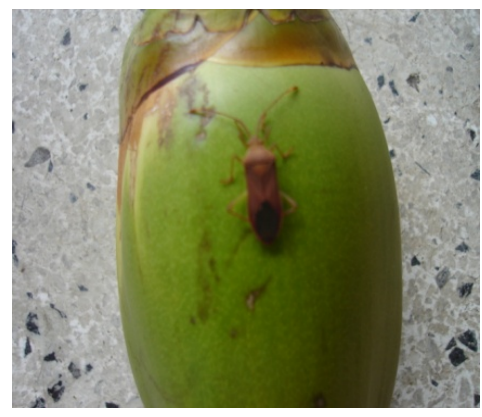

Plate 3. Premature nut fall

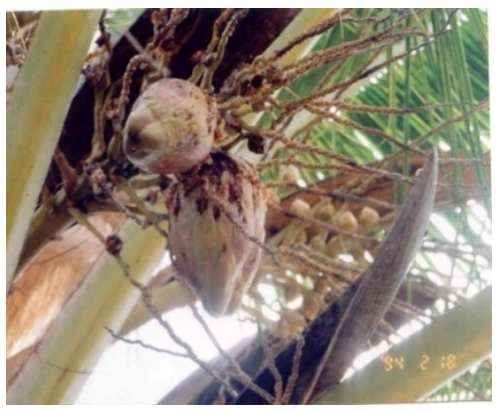

Plate 4. Scarred and gumming nuts

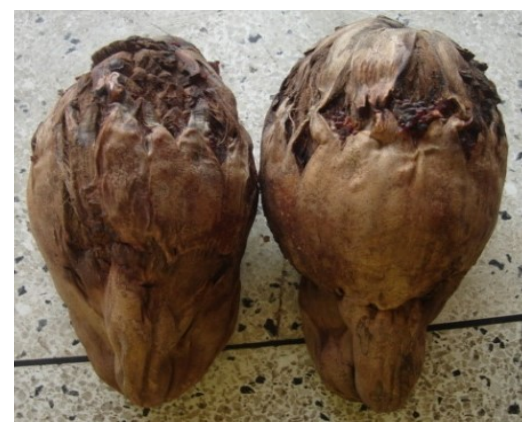




\section{Eriophyid mite (Aceria guerreronis)}

The mite was first noticed in the East African Region in the early 1990. Since then, the insect has aggressively spread throughout Kenya and Tanzania. Estimated damage of the crop by the insect is $20-30 \%$. The attacked nuts are usually small in size with less copra. Nuts also fall prematurely leading to low yields. In addition to nut damage, the mites also affect the husk thereby reducing the quality of coir. Observations made to the nuts in the coconut trees during the survey revealed that at least $40 \%$ of the trees in the farms had nuts that were affected by the mites. The adult mites enter the nuts through the bracts of young nuts by crawling. They infest the area under bracts and start feeding on the nut thereby causing scarring damage. This results in scarified tissues of the nut and hence an arrested growth with the nut failing to fully expand. The attacked nut is usually/may be diminutive. In most cases farmers are deceived into premature harvesting as the nuts look like they have reached maturity stages due to the colour of the husk. As the mites start entering the nut through the bract, a scar starts developing as feeding continues. The scar then develops gradually downwards and sideways eventually covering the whole nut as shown in the figure (Plate 5) below.

Plate 5. Developing nuts attacked by Eriophyid mites

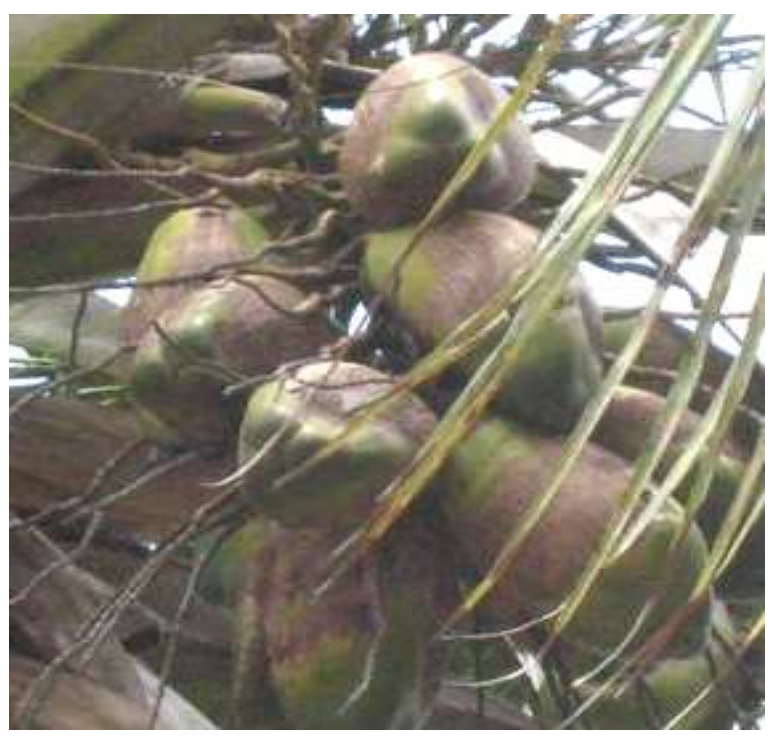

All the farmers interviewed indicated that they had no knowledge on how to control the pest. In fact many of them believed that it was one of the coconut diseases that had no cure. It is therefore important for research to be conducted so as to come up with appropriate technologies that can be used to effectively control the pest.

\section{Coconut diseases}

Only $30 \%$ of the respondents could differentiate between pest attack and disease infestation respectively while the rest could not. The only disease that the farmers could identify was the coconut bole rot. The disease is caused by the Basidiomycete (Marasmiellus cocophilus) Pegler (van Eijnatten, 1979). They indicated that the disease mostly affects the young palms of the tall variety. Affected trees usually exhibit a wilt of the leaves followed by yellowing and browning. The leaves eventually die back but remain attached to the trunk as a 'skirt'. The bud develops a wet rot and the bole a dry red-brown rot (Rock et.al, 1970).

A narrow yellow margin and cavities lined with fungal mycelium occurs at the base of the bole and the roots are destroyed. Eventually the spear leaf dies and a foul-smelling soft rot develops at the base of the leaves and spathes. Thereafter, a reddish dry rot with a narrow yellow margin and cavities lined with fungal mycelium occurs at the base of the bole.

Eventually the roots are destroyed. Early infections destroy the embryo leading to invasion of the nut cavity and colonization of the endosperm. Later, the infections are seen as areas of white or pinkish mycelium on the shoot, which may cause rots and slow the development or in most cases post-emergence death (Peries, 1974). The disease has caused some substantial deaths to coconut palms in some regions of the coastal Kenya, notably Rabai and Kaloleni SubCounties of Kilifi County. Farmers have no knowledge on how to control the disease. Most of them (98\%) said that once they notice the symptoms, they usually cut down the tree for timber. This could be one way but after cutting down and splitting the timber, the trunk is left in the field and more infestations continue. There is 
need to develop appropriate technologies for the control of this economic important disease.

\section{Conclusion and recommendations}

The study revealed that coconut farming is a major income generating enterprise for the smallholder farmers in Coastal Kenya. At the same time coconut is a food security crop as it has the ability of producing nuts throughout the year under favourable climatic conditions. Coconut farming is however faced with a number of challenges that include limited varieties, aging trees, the effects of climate change and poor agronomic practices that contribute to low yields. Other challenges of economic importance are the incidences of pests and diseases. Among the major pests of economic importance that cause severe damage to the trees and nuts include the rhinoceros beetle, termites, Coreid bug and the Eriophyid mite. The Rhinoceros beetle attacks both the young and the old palms leading to stunted growth and eventual death of coconut palms. The study revealed that $80 \%$ of the coconut palms in coastal Kenya are affected by the rhinoceros beetle. Farmers have inadequate knowledge on how to control the pest. At the same time, the farmers are unknowingly encouraging the multiplication of the pest by leaving heaps of coconut waste that include dead coconut trees, husks, shells, fronds and leaves of coconut as well as manure from animals. These materials act as breeding sites for the rhinoceros beetle.

Termites on the other hand were found to be pests that were also causing damage to the coconut palms especially the young trees. However, the pest can easily be controlled by use of chemicals. Nuts are also heavily affected by pests that include the Coreid bug and the Eriophyid mite. The Coreid bug attack young nuts and feeds on it by sucking sap from the nut leading to premature nut fall. For those nuts that manage to survive the attack, they usually have scarred husks. The bug can cause damage of up to $80-90 \%$. The Eriophyid mite is another pest of economic importance that was found to have affected over $40 \%$ of the trees. The mite enters the young nut through the bract and starts feeding. The end result is a scar that develops gradually downwards and sideways covering the whole nut. Severely affected nuts fall off from the tree prematurely. Those that manage to survive have a stunted growth with small nuts that have poor quality copra. The husks are also of poor quality. Farmers may even be tempted to harvest the nuts early owing to the browning of the husks. The pest is capable of causing damage of $20-30 \%$ loss. The only major disease of economic importance that was reported is the coconut bole rot. It has the potential of destroying up to $30 \%$ of the young coconut palms if not controlled in its early stages.

\section{Recommendations}

In an effort to revitalize coconut production and productivity in coastal Kenya, the study recommends that some technological packages be developed to address the challenges of pests and diseases, notably the Rhinocerous beetle, Coreid bug and the Eriophyid mite as well as the bole rot disease. The technologies to be developed or adopted from other coconut producing countries should be user friendly to the farmers and they should also be useful in conserving the environment.

\section{Acknowledgements}

The authors are grateful to the Managing Director, KCDA for allowing the study to be undertaken and the provision of financial support. The Centre Director, KARI-Mtwapa for allowing his staff to participate in the study, the Vice Chancellor Pwani University for allowing his staff to take an active role in the study, the Sub County Agricultural Officers in all the Counties that the study was undertaken for allowing their Frontline Extension Officers to help in administering the questionnaire and data collection Last but not least all the KARIMatuga staff for organizing and distribution of the questionnaires for data collection. To you all we say THANK YOU.

\section{References}

Anon, 1999. Mother-Infant HIV Transmission could be reduced through viral lowering with Lauric and Carpric Acid. Lauric.org 
Anon, 2001. Results Analysis of Clinical HIV Trial with Monoglycerides. Lauric. Org

Central Bureau of Statistics, Government of Kenya. 2003. Geographic dimensions of well-being in Kenya. Volume 1: Where are the people? From districts to locations. Central Bureau of Statistics, Ministry of Planning and National development, and International Livestock Research Institute. Nairobi, Kenya.

Gachanga G., Odhiambo Z. and Musinga M. (2007). The coconut sub-sector in Kenya. Baseline survey report. ABDDNAIDA/CDA. 55p. 2 Appendix.

Peries, O. S., (1974). Ganoderma basal stem rot of coconut: a new record of the disease in Sri Lanka. Plant Dis Reptr. 58, 293-295.

Sihag K.C., (1997). Pollination Biology: Basic and applied principles. Rajendra scientific publishers, Hissar, 210pp.

Sharma, K L. (2006) Food Security in the South Pacific Island Countries with Special Reference to the Fiji Islands June 2006.

Rock, R.K., Ivory, M.H. and Adams, B, R., (1970). Lethal bole rot disease of coconut in East Africa. Ann. Appl. Biol., 66,455464

Van Eijnatten, C.L.M., (1979); Summary of Information on Coconuts in Coast Province and Proposals for future work. C.A.R.S. Communication No. 4; August 1979, 12pp. 